\title{
Bone and tissue reaction of porous nickel-titanium alloy implant for dental implants in rabbits
}

\author{
Gwi-Hyeon Min ${ }^{1}$, Kyoung-Hoon Lee², Se-Jin Sung ${ }^{2}$, Won-Pyo Lee², Sang-Joun Yu², and Byung-Ock Kim ${ }^{2 \star}$ \\ ${ }^{1}$ Top Plant Dental Clinic, Iksan, Republic of Korea \\ ${ }^{2}$ Department of Periodontology, School of Dentistry, Chosun University, Gwangju, Republic of Korea
}

Porous nickel-titanium (Ni-Ti) alloy implants have been previously introduced, and many studies have been performed. Porous $\mathrm{Ni}$ - Ti alloys have excellent properties for use in the dental field. Thus, the use of a porous $\mathrm{Ni}$-Ti coating to combine the advantages of $\mathrm{Ni}$-Ti with titanium implants should be considered. The aim of this study was to investigate the tissue response to porous $\mathrm{Ni}$-Ti alloy in vivo. Three 8-mm diameter calvaria bone defects were established in New Zealand rabbits. In the control group, only a collagen membrane was applied to the defect. In experimental group I, the alloy disk was applied to the defect with a bone graft and resorbable membrane. In experimental group II, the alloy disk was placed in the defect covered by a resorbable membrane. After 4 and 8 weeks of healing, the experimental animals were euthanized for specimen preparation. Histomorphometric analysis was performed to quantify new bone formation and connective tissue. The data were analyzed by Kruskal-Wallis and Mann-Whitney U-tests. At 4 and 8 weeks, new bone formation was seen in all groups. The new bone formation was insufficient in the groups with the titanium implants. There was minor inflammation in the experimental groups compared with the control group. In this study, new bone formation and tissue reactions were seen around the porous Ni-Ti alloy. Minor inflammation and insufficient new bone formation were noted in the experimental groups. This meant that the porous Ni-Ti alloy affected the adjacent tissue.

Key Words: Bone regeneration, Bone-implant interface, Dental implant

(c) This is an open-access article distributed under the terms of the Creative Commons Attribution Non-Commercial License (http://creativecommons.org/licenses/by-nc/4.0) which permits unrestricted noncommercial use, distribution, and reproduction in any medium, provided the original work is properly cited.

\section{서 론}

치과용 임플란트는 상실된 저작기능과 심미적 회복을 원하는 환자들의 요구에 부합하는 치아의 대체제로 치과 영역에서 큰 역할을 수행하고 있다. 치과용 임플란트는 재료와 기술적인 부 분에서 짧은 기간 많은 발전을 이루었다. 현재는 티타늄 계열의 치과용 임플란트가 주를 이루고 있는데, 2000년 초, 중반에는 nickel-titanium (Ni-Ti)합금을 이용한 임플란트에 대한 연구가 많이 이루어졌다.
$\mathrm{Ni}-\mathrm{Ti}$ 합금은 1959년 Buehler 등[1]과 Wang 등[2]에 의해 발 견된 물질로 형상기억과 초탄성의 특별한 특성을 가지고 있다. 의료 분야에서는 이러한 성질을 이용한 의료 용품이 제조되어 다양하게 활용하고 있다. 다공성을 가진 $\mathrm{Ni}-\mathrm{Ti}$ 합금은 골과 융합 이 필요한 분야에서 이용되고 있는데, 최초로 상용화된 다공성 $\mathrm{Ni}-\mathrm{Ti}$ 합금으로 제조된 의료용품은 2002년 정형외과에서 요추 와 경추를 치료하기 위해 만들어진 척추 대체제였다[3]. 임상적 으로 다공성의 $\mathrm{Ni}-\mathrm{Ti}$ 합금은 $\mathrm{Ni}-\mathrm{Ti}$ 합금 자체 고유의 특성을 가 지면서 생체 친화성과 우수한 골융합을 확인할 수 있었다. 이를

Received October 4, 2019; Revised November 18, 2019; Accepted November 18, 2019

*Corresponding author: Byung-Ock Kim, Department of Periodontology, School of Dentistry, Chosun University, 309 Pilmun-daero, Dong-gu, Gwangju 61452, Republic of Korea.

Tel: +82-62-220-3850, Fax: +82-62-224-4664, E-mail: bobkim@chosun.ac.kr 
기반으로 치과영역에서도 치과용 임플란트에 다공성의 $\mathrm{Ni}-\mathrm{Ti}$ 합 금을 적용하려는 연구가 진행되었다[4]. 골유착에 유리한 다공 성의 구조를 가진 Ni-Ti합금 치과용 임플란트는 오스테나이트 (austenite)상에서 휘어지고, 마텐자이트(martensite)상에서 곧 은 형태를 갖도록 제작되었다. 이는 $\mathrm{Ni}-\mathrm{Ti}$ 의 형상기억 특성을 이용하여 골 내에 식립된 임플란트가 온도가 높아짐에 따라 오 스테나이트상으로 변이되면서 휘어져 기계적인 고정을 얻으려 는 시도였다. 하지만 이전에 제작된 $\mathrm{Ni}$-Ti합금 치과용 임플란트 는 형태가 일정하지 않아 표준화된 방식으로 식립이 어려웠다. 또한, 임플란트에 문제가 생겼을 때 제거가 어렵다는 단점으로 인해, 직선형 임플란트에 비해 착탈(retrievability)이 쉽지 않았 다. 그리고 니켈 이온(Ni+)의 용출 가능성 등의 문제도 제기되 어 생체 안정성에 대한 논란도 이어졌다. 이로 인해 임상적용이 어려웠고 현재는 다공성의 Ni-Ti합금으로 제조되는 치과용 임 플란트에 대한 연구가 많이 이뤄지지 않고 있다. 하지만 $\mathrm{Ni}-\mathrm{Ti}$ 합금이 가지고 있는 생체친화성, 우수한 골융합, 형상기억, 초 탄성 같은 특성은 치과용 임플란트에 있어 분명히 가치 있는 성 질들이다. $\mathrm{Ni}-\mathrm{Ti}$ 합금의 생체친화적인 특성은 니켈 이온의 용출 이 없는 가정하에서 가능한데, 표면처리가 충분히 이루어진다 면 니켈 이온의 용출을 감소시켜 다공성의 Ni-Ti합금은 생체친 화적인 재료로 사용될 수 있다. 또한, 다공성의 구조는 골조직의 침투가 용이하고 훌륭한 골유착을 형성할 수 있는 환경을 제공 해 준다. 그리고 부가적으로 형상기억의 특성은 기계적인 적합 성을 높여줄 수 있고, 초탄성은 외력에 대해 버틸 수 있는 영역 을 넓여주고 stress shielding effect를 감소시킬 수 있어 안정적 인 골유착을 유지시키고 파절을 방지할 수 있는 구조적인 안정 성을 준다.

지금까지 티타늄 임플란트의 발전은 골유착을 향상시키기 위 한 형태와 표면처리의 변화를 통해 이루어져 왔다. Sandblast Large grit Acid etch, titanium plasma spray같이 티타늄 표면 에 거친 표면을 부여한 후 화학적으로 hydroxyapatite, $\mathrm{Mg}, \mathrm{Sr}$, $\mathrm{F}, \mathrm{Ca}-\mathrm{P}$ 등을 코팅하여 골유착에 유리한 환경을 만들어 주는 형 태로 이루어졌던 부분으로[5], 다공성 $\mathrm{Ni}-\mathrm{Ti}$ 합금의 우수한 다공 성의 구조를 티타늄 임플란트의 표면에 적용하는 방식을 적용 할 수 있다면 골유착에 우수한 환경을 제공할 수 있을 것이다. 그리고 부가적인 Ni-Ti합금의 특성을 전달할 수 있을 것이다.

이번 연구는 in vivo상에서 다공성의 $\mathrm{Ni}$-Ti합금의 조직 반응 을 살펴보는 데 목적이 있다. 향후 코팅제로 활용할 수 있는 다 공성의 $\mathrm{Ni}-\mathrm{Ti}$ 합금의 생물학적 안정성은 이식 부위 주변의 조직 반응 및 골형성을 통해 확인이 가능하다. 이를 위해 가토의 두개 골에서 원판 형태의 다공성 $\mathrm{Ni}-\mathrm{Ti}$ 합금을 제작해 적용했고, 주변 의 신생골 생성 및 염증 반응을 관찰하였다.

\section{대상 및 방법}

\section{실험 재료}

본 연구는 조선대학교 동물윤리위원회의 승인(CIACUC2017 A0010)을 받아 진행되었다. 실험은 1년생 3-3.5 kg 10마리 수 컷 토끼(New Zealand rabbit)를 이용하여 각 5마리씩 4, 8주군 으로 나눠 진행했다.

실험에 사용된 시편은 니켈과 티타늄이 1:1의 비율로 혼합된 다공성 $\mathrm{Ni}$-Ti합금(Human Cross, Gwangju, Korea)을 이용하 여 제작하였다. 시편은 실험에 이용될 골결손부 형태를 고려하 여 직경 $8 \mathrm{~mm}$, 두께 $1 \mathrm{~mm}$ 의 원판 형태로 가공하여 사용하였 다.

원판의 다공성 구조는 SHS (self-propagating high temperature synthesis)방식으로 형성하였다. 표면처리를 위해 1차 산세척, 2차 10 분 간 식염수세척, 3 차 $100^{\circ} \mathrm{C} 30$ 분 간 중탕 가열 하였다. 만들어진 시편은 $25-40 \mathrm{kGy}$ 의 감마선을 이용해서 살 균하였다.

\section{실험 방법}

토끼를 Ketamine- $\mathrm{HCl}(5 \mathrm{mg} / \mathrm{kg}$ )과 Xylazine $\mathrm{HCl}(1.5 \mathrm{~mL} /$ $\mathrm{kg}$ )으로 마취시킨 후, 두 개 부위의 털을 깎고 소독 후, 골막을 포함한 전층판막으로 거상하였다. $8 \mathrm{~mm}$ trephine bur (Biomet 3i, Palm Beach Gardens, FL, USA)를 이용하여 두개골에 뇌막 까지 접근되도록 관통된 3개의 골결손부를 형성하였다(Fig. 1). 형성된 골결손부에는 각각 대조군과 2 개의 실험군을 설정하였 다. 대조군은 다공성 $\mathrm{Ni}-\mathrm{Ti}$ 합금 원판 없이 골결손부를 흡수성 차폐막(CollaGuide ${ }^{\circledR}$; IB Dental, Seongnam, Korea)으로만 피 개하였다. 실험군 I은 다공성 $\mathrm{Ni}-\mathrm{Ti}$ 합금 원판을 골결손부에 적 용하고 이종골(Intergraft ${ }^{\circledR}$, Cellumed, Seoul, Korea)을 상방에 약 $1 \mathrm{~mm}$ 높이로 적용하고 흡수성 차폐막(CollaGuide ${ }^{\circledR}$ )으로 덮 어주었다. 실험군 II는 다공성 Ni-Ti합금 원판을 적용하고 골이 식재 없이 흡수성 차폐막(CollaGuide ${ }^{\circledR}$ )만으로 피개하였다. 각 각의 재료를 적용 후에 흡수성 봉합사(vicryl 5-0, Ethicon Inc., Norderstedt, Germany)를 이용해서 고정될 수 있도록 골막에 수평 누상 봉합을 시행하였다.

창상은 흡수성 봉합사로 단속봉합 시행하였다. 술 후 2 일 동 안 gentamicin $(0.1 \mathrm{mg} / \mathrm{kg})$ 을 피하 주사하였다.

수술 4주, 8 주 후에 토끼의 정맥 내에 $\mathrm{KCl}(1 \mathrm{mg} / \mathrm{kg})$ 를 주사 하여 희생시켰다. 토끼의 두개골을 전층판막으로 거상한 후 reciprocal saw를 사용하여 이식부위를 침해하지 않고 조심스럽 게 두개골을 제거하였다(Fig. 2A, B). 

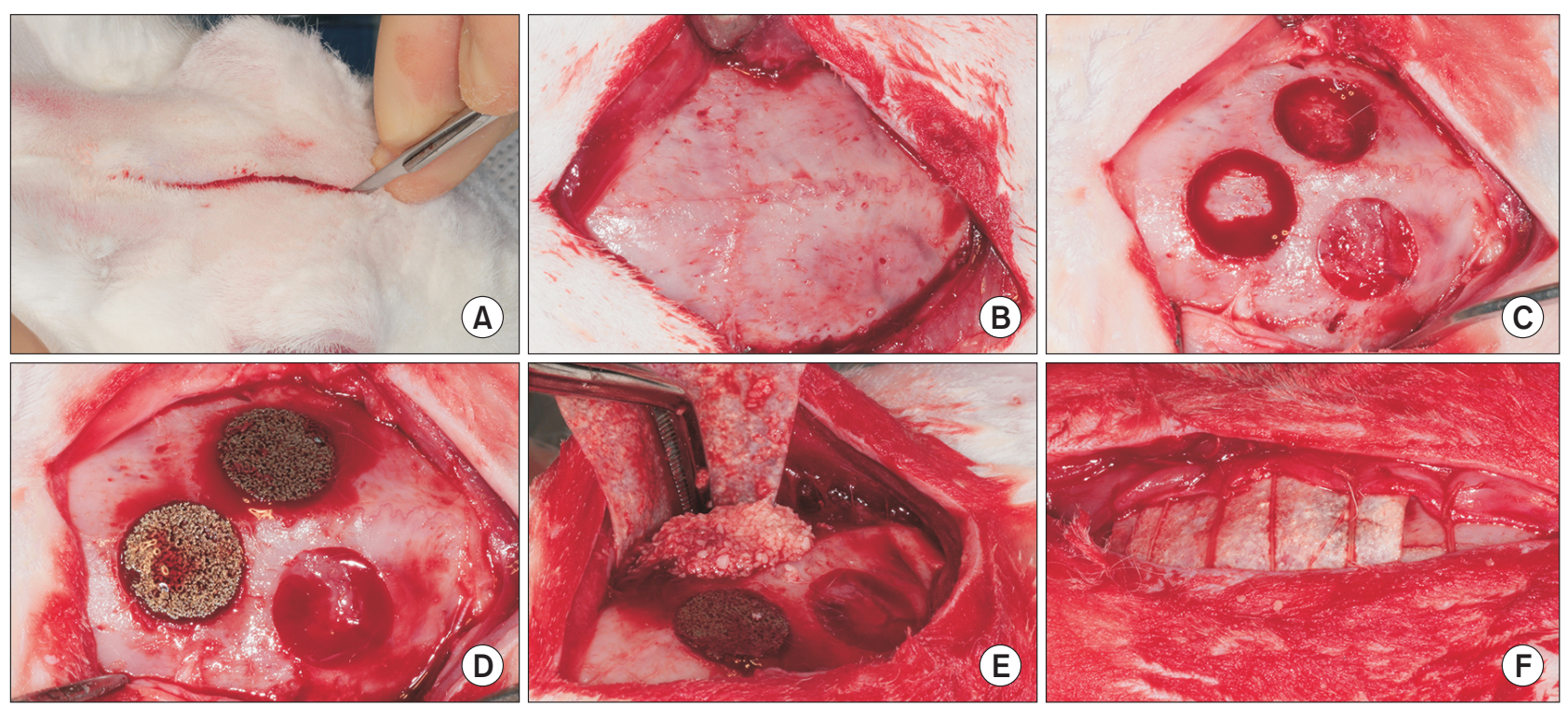

Fig. 1. Experimental procedure. (A) Incision on the rabbit's head, (B) elevation of full thickness flap, (C) three bone defects on the rabbit's calvaria, (D) (1) control group, (2) experimental group I, (3) experimental group II. (E) Applying experimental materials to the bone defect (control group: resorbable membrane, experimental group I: porous $\mathrm{Ni}$-Ti disc+xenograft+resorbable membrane, experimental group II: porous $\mathrm{Ni}-\mathrm{Ti}$ disc+resorbable membrane). (F) Fixation of collagen membrane with holding suture with absorbable suture material.
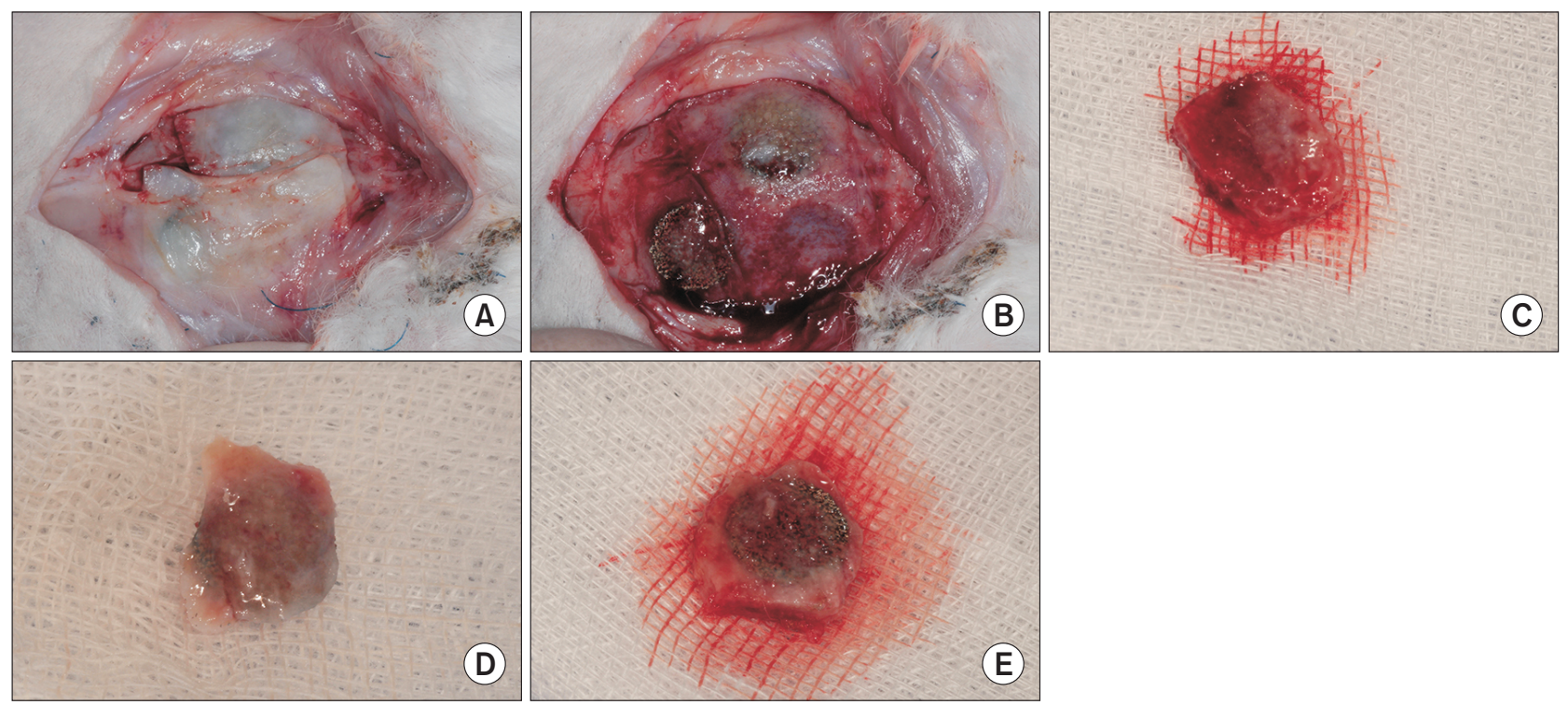

(C)

Fig. 2. Sacrifice experimental procedure (4 weeks). (A) After 4 weeks, rabbit was sacrificed and surgical site was opened. Collagen membrane was retained well. (B) After removal of collagen membrane, surgical site was seen healthy tissue status with applying materials. (C) Control group specimen, (D) experimental I group specimen, (E) experimental II group specimen.

\section{Histomorphometric analysis}

제거된 두개골 절편을 $4 \%$ paraformaldehyde 용액에 고정하 였으며, 탈회용액(hydrochloric acid; Fisher Scientific, Tustin, $\mathrm{CA}$, USA)에서 2-4주 동안 $4^{\circ} \mathrm{C}$ 에서 탈회한 후 통법에 따라 탈수
하고 파라핀에 포매하였다. 포매된 절편을 $6 \mu \mathrm{m}$ 두께로 박절하 고 hematoxylin-eosin염색을 시행했다. 준비된 시편은 광학 현 미경을 통해 관찰하였고, 조직상은 MagnaFire digital camera system (Optronics ${ }^{\circledR}$, Goleta, CA, USA)으로 얻었다. 얻은 조직 상에서 Visus Image Analysis System (Image \& Microscope 
Technology, Daejeon, Korea)을 이용해서 신생골, 결합조직량 을 계측하였다. 또한 시편 부위의 염증세포 침윤 양상 관찰을 통 하여 조직 염증의 유, 무를 평가하였다.

\section{통계처리}

대조군과 실험군의 반복 실험을 걸쳐 평균을 표시하였다. 자 료의 통계 분석은 SPSS ver. 20.0 software (IBM Corp., Armonk, NY, USA)를 사용하였다. 각 군마다의 유의적 차이를 확 인하기 위해서 Kruskal-Wallis와 Mann-Whitney test을 이용 하였고, 유의수준 $p<0.05$, 신뢰수준 $95 \%$ 에서 검증하였다.

\section{결 과}

\section{4주군}

\section{대조군}

전체적으로 신생골의 비율이 높았다. 조직계측학적 분석을 통해 신생골은 $41.30 \% \pm 7.42 \%$, 결체조직은 $58.70 \% \pm 7.42 \%$ 의 비율을 확인하였다. 염증 반응은 5마리 중 4마리에서는 음성으 로 나타났고, 1마리에서 양성을 나타내었다(Table 1).

Table 1. Tissue response in 4 weeks control and experimental groups $(\mathrm{n}=5)$

\begin{tabular}{lccccc}
\hline & \multicolumn{5}{c}{ Inflammation } \\
\hline No. of rabbit & 1 & 2 & 3 & 4 & 5 \\
Control group & - & - & - & - & + \\
Experimental group I & + & + & + & + & + \\
Experimental group II & + & + & + & + & + \\
\hline
\end{tabular}

Control group: resorbable membrane, experimental group I: porous $\mathrm{Ni}$-Ti disc+xenograft+resorbable membrane, experimental group II: porous $\mathrm{Ni}-\mathrm{Ti}$ disc+resorbable membrane.

Table 2. Percentage of new bone and connective tissue in 4 weeks groups

\begin{tabular}{lcc}
\hline \multicolumn{1}{c}{ Group } & NB & CT \\
\hline Control group & 41.30 & 58.70 \\
Experimental group I & 33.17 & 66.83 \\
Experimental group II & 9.93 & 90.07 \\
\hline
\end{tabular}

Values are presented as mean.

Control group: resorbable membrane, experimental group I: porous $\mathrm{Ni}$-Ti disc+xenograft+resorbable membrane, experimental group II: porous Ni-Ti disc+resorbable membrane.

$\mathrm{NB}$, new bone; CT, connective tissue.

\section{실험군 |}

적용했던 흡수성 차폐막은 약간 흡수된 상태로 원형 상태를 유지하고 있었다. 다공성 $\mathrm{Ni}-\mathrm{Ti}$ 합금 원판 상부에 적용했던 골이 식재 주변으로 골형성이 원활히 이루어진 것으로 보였고, 표면 경도는 단단한 상태였다(Fig. 2D). 조직계측학적 분석을 통해 신생골은 $33.17 \% \pm 27.33 \%$, 결체조직은 $66.83 \% \pm 27.33 \%$ 였다 (Table 2). 신생골의 비율은 대조군에 비해 적었고, 신생골에 비 해 결체조직의 양이 많았다(Fig. 3). 염증은 5마리 모두에서 양 성을 나타내었다.

\section{실험군 II}

조직계측학적 분석시 신생골 $9.93 \% \pm 5.46 \%$, 결체조직 $90.07 \% \pm 5.46 \%$ 를 나타내었다. 신생골의 형성이 다른 군에 비 해서 저조했다(Fig. 4). 실험군 I의 30\%정도의 신생골 형성이 이 루어진 상태였다. 조직편을 육안으로 봤을 때 원판 상부가 결합 조직에 쌓인 채로 노출되어 있었고, 가장자리 부위에서만 골형 성 양상 관찰되었다(Fig. 2E). 염증은 5마리 모두에서 양성으로 나타났다.

\section{8주군}

\section{대조군}

조직계측학적 분석을 통해 신생골은 $19.60 \% \pm 23.91 \%$, 결체 조직은 $80.40 \% \pm 23.91 \%$ 의 비율을 확인하였다. 신생골의 비율 은 4주군에 비해서 약 $50 \%$ 감소했다. 염증 반응은 5마리 모두 음성으로 나타났다(Table 3).

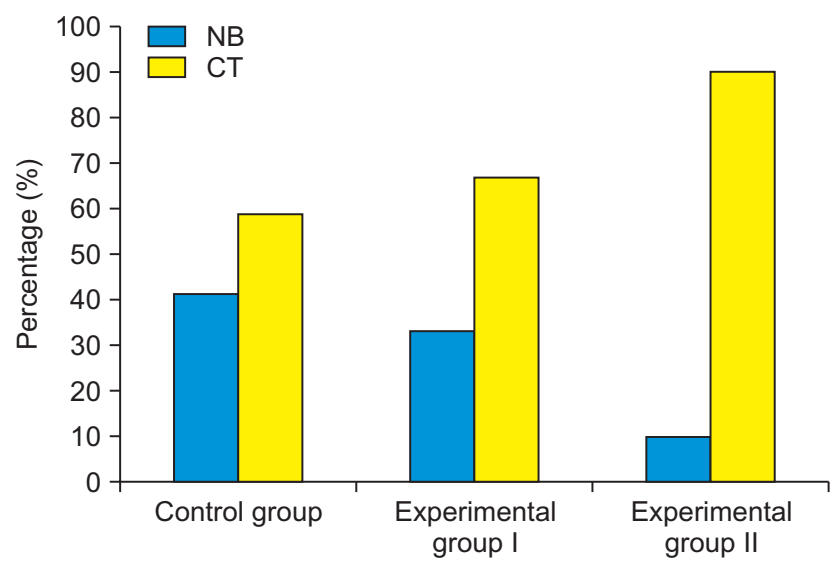

Fig. 3. Histogram illustrating of the percentage of new bone and connective tissue at 4 weeks. The highest new bone volume was the control group compared to the experimental groups. Between experimental groups, experimental group I was about three times as large as new bone compared to the experimental group II. NB, new bone; CT, connective tissue. 

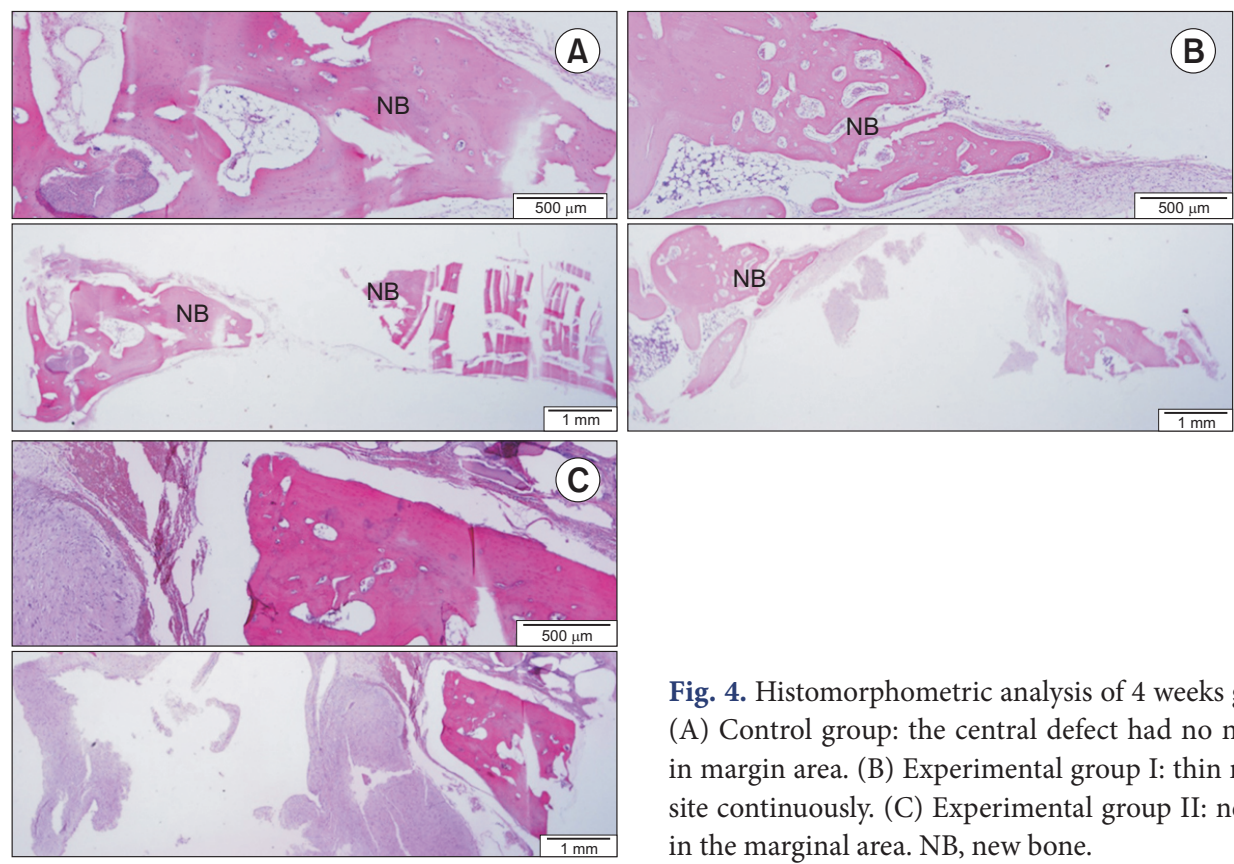

Fig. 4. Histomorphometric analysis of 4 weeks groups (hemotoxylin and eosin staining). (A) Control group: the central defect had no new bone formation. New bone was seen in margin area. (B) Experimental group I: thin new bone was seen in bone central defect site continuously. (C) Experimental group II: new bone and connective tissue were seen in the marginal area. NB, new bone.

Table 3. Tissue response in 8 weeks control and experimental groups $(\mathrm{n}=5)$

\begin{tabular}{llllll}
\hline & \multicolumn{5}{c}{ Inflammation } \\
\hline No. of rabbit & 1 & 2 & 3 & 4 & 5 \\
Control group & - & - & - & - & - \\
Experimental group I & + & + & + & + & + \\
Experimental group II & + & + & + & - & + \\
\hline
\end{tabular}

Control group: resorbable membrane, experimental group I: porous $\mathrm{Ni}$-Ti disc+xenograft+resorbable membrane, experimental group II: porous $\mathrm{Ni}$-Ti disc+resorbable membrane.

Table 4. Percentage of new bone, residual bone graft and connective tissue at 8 weeks

\begin{tabular}{lrc}
\hline \multicolumn{1}{c}{ Group } & NB & CT \\
\hline Control group & 19.60 & 80.40 \\
Experimental group I & 40.77 & 59.23 \\
Experimental group II & 6.27 & 93.73 \\
\hline
\end{tabular}

Values are presented as mean.

Control group: resorbable membrane, experimental group I: porous $\mathrm{Ni}-\mathrm{Ti}$ disc+xenograft+resorbable membrane, experimental group II: porous $\mathrm{Ni}$-Ti disc+resorbable membrane.

$\mathrm{NB}$, new bone; $\mathrm{CT}$, connective tissue.

\section{실험군 I}

조직계측학적 분석을 통해 신생골은 $40.77 \% \pm 33.00 \%$, 결체 조직은 $59.23 \% \pm 33.00 \%$ 였다(Table 4). 신생골의 비율은 4주군 에 비해 증가했다. 염증은 5마리 모두에서 양성을 나타내었다.

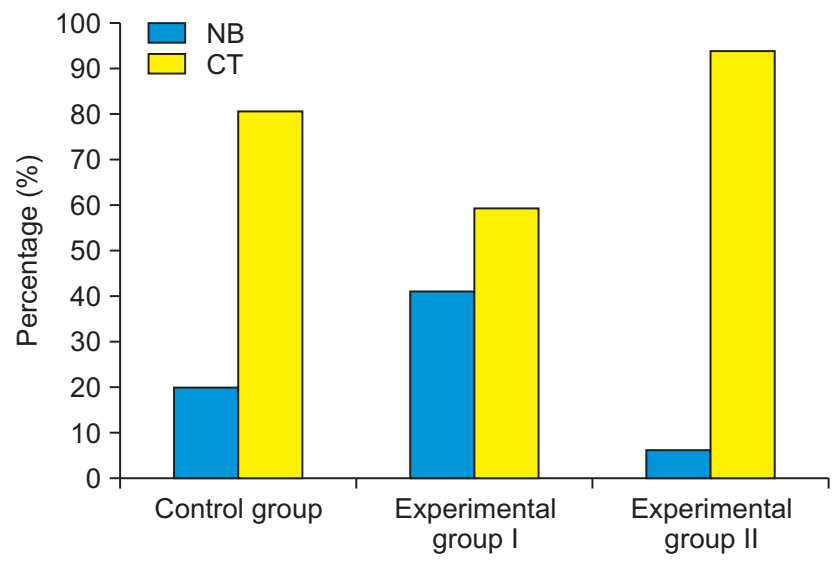

Fig. 5. Histogram illustrating of the percentage of new bone and connective tissue at 8 weeks. The highest new bone volume was the experimental group I compared to other groups. Between experimental groups, the difference of new bone volume was greater than 4 weeks. $\mathrm{NB}$, new bone; CT, connective tissue.

\section{실험군 II}

조직계측학적 분석 시 신생골 $6.27 \% \pm 2.01 \%$, 결체조직 $93.73 \% \pm 2.01 \%$ 를 나타내었다. 신생골의 형성이 다른 군에 적 었고(Fig. 5), 4주군에 비해 약 30\% 감소했다. 조직의 대부분은 결체조직이었다(Fig. 6). 염증은 5마리 중 4마리에서 양성으로 나타났고, 1마리에서 음성을 보였다.

4, 8주군 모두 신생골, 결합조직 비율에서 통계적으로 유의한 차이는 없었다. 4주, 8주군 간을 비교 시에도 신생골, 결합조직 비율 모두에서 통계적으로 유의한 차이는 없었다. 

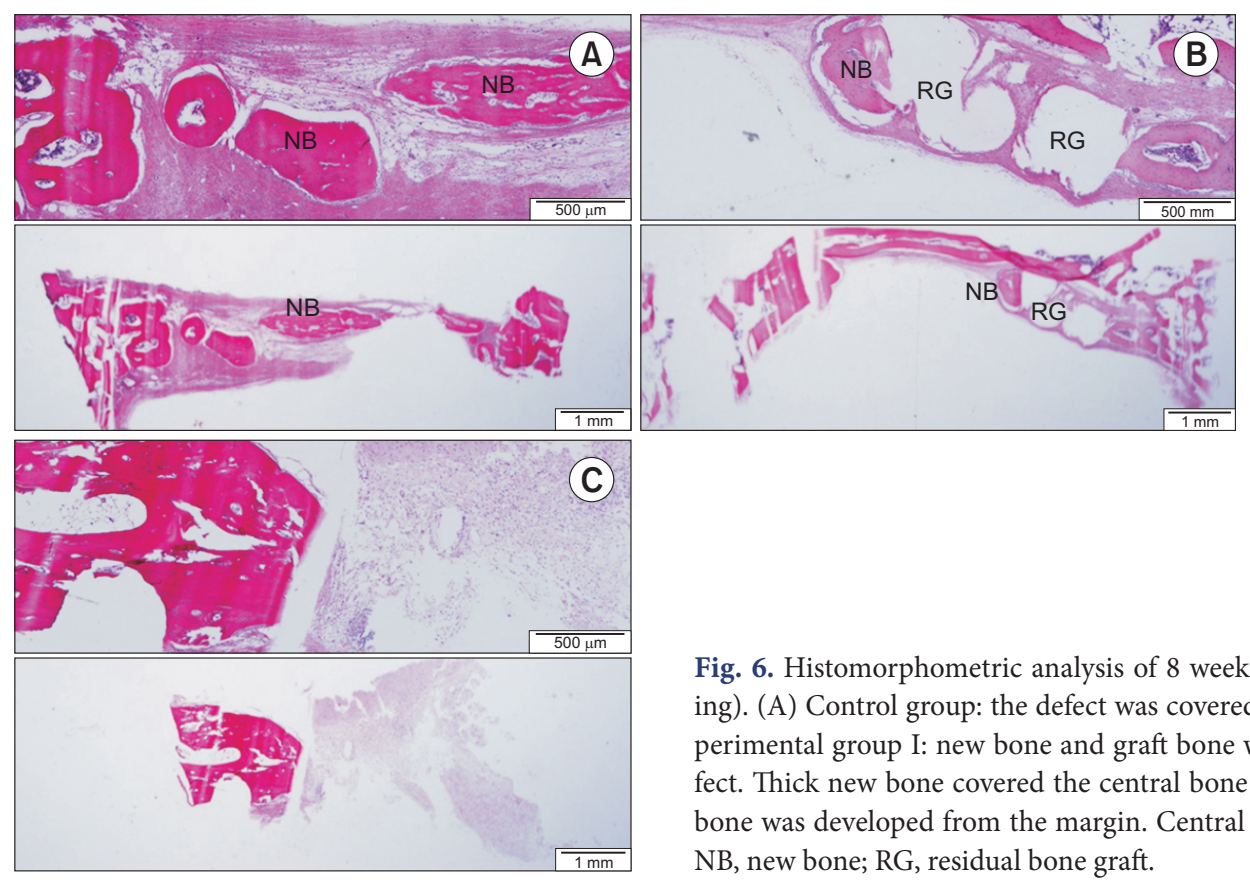

Fig. 6. Histomorphometric analysis of 8 weeks groups (hemotoxylin and eosin staining). (A) Control group: the defect was covered by new bone from the margin. (B) Experimental group I: new bone and graft bone were seen continuously in the entire defect. Thick new bone covered the central bone defect. (C) Experimental group II: new bone was developed from the margin. Central defect was filled with connective tissue. $\mathrm{NB}$, new bone; RG, residual bone graft.

\section{고 찰}

이번 논문의 목적은 다공성 Ni-Ti합금의 in vivo상에서 골형 성 여부 및 염증반응을 평가하여 조직 반응의 정도를 살펴보는 것이었다. 술 후 4주와 8주에 조직학적 평가에서 신생골의 비율 은 실험군 I은 각각 $33.17 \%, 40.77 \%$, 실험군 II는 9.93\%, $6.27 \%$ 으로 나타났다. 실험군 I과 실험군 II의 차이는 골이식재에 적용 여부에 따른 것으로 실험군 II의 경우는 골이식재를 상부에 적용 하지 않아 골재생이 일어날 공간 확보가 되지 못해 신생골 비율 이 낮게 나온 것으로 생각된다. 대조군에서의 신생골의 비율은 4 주군에 비해 8 주군에서 낮게 나타났는데 이는 토끼 개별 개체 의 차이로 인한 것으로 생각된다. 조직 반응은 실험군 모두에서 약간의 염증이 관찰되었다. 대조군은 4 주군에서 1 개체에서만 양성을 나타냈다. 하지만 실험군 I에서는 4,8 주군 모두에서 양 성을 나타냈고, 실험군 II는 4주군 모두 양성을 보였고, 8 주군은 1 개체만 음성을 보였다. 염증반응은 염증의 유무를 조직형태학 적으로 확인한 것으로, 대조군에 비해 실험군에서 염증이 관찰 되었다. 이는 다공성 Ni-Ti합금에 의한 영향으로 실험군에서 치 유가 느리게 진행된 것으로 생각된다. 치유가 진행되면서 염증 상태가 개선된 것을 관찰할 수 있었고, 신생골 형성 자체에 영향 을 주지는 않았다.

다공성 $\mathrm{Ni}-\mathrm{Ti}$ 합금은 니켈과 티타늄이 1:1의 비율로 혼합된 물질로 SHS방식으로 제조되었다[6]. SHS방식은 니켈이온과 티 타늄이온 사이의 발열반응이 연쇄적으로 진행되면서 발생하는 내부 폭발을 이용해서 다공성의 구조를 만드는 방법이다. 다공
성과 평균적인 공간의 크기는 압력과 온도를 이용해서 일정부 분 조절할 수 있다. 압력을 감소시킨 상태에서 공간 조절 물질 $\left(\mathrm{NH}_{4} \mathrm{HCO}_{3}, \mathrm{Mg}, \mathrm{NaCl}, \mathrm{NaF}\right)$ 을 추가하면 다공성을 증가시킬 수 있고 $[7,8]$, 반응 온도를 변화 시키면 공간의 크기를 조절할 수 있 다. 이후 온도를 일정하게 유지시키면 균일 다공성 상태로 만들 수 있다. SHS방식을 통해 다공성은 50\%정도 형성된다. SHS방 식의 장점은 적은 에너지 사용, 상대적으로 단순한 과정, 높은 다공성, 저렴한 가격이다. 하지만 온도 및 압력 조절이 잘못될 경우, 너무 많은 다공구조와 큰 공간 크기를 형성시킬 수 있다. 그리고 짧은 시간과 높은 가열 비율 때문에 완전히 반응하지 못 한 잔여 물질이 남아 2차상이 나올 수 있다[9]. 이는 SHS과정 속 에서 금속간 상(intermetallic phases)을 조절하는 것이 불가능 해서 발생하는 것으로 Ti2Ni, Ni3Ti, Ni4Ti3와 같은 2차 중간산 물이 형성된다. 이러한 물질이 많을 경우 취성파괴 현상이 발생 할 수 있기 때문에 적절한 온도와 시간 동안 반응이 일어나도록 해야 한다[10].

이렇게 형성된 다공성의 구조는 골조직에 생체 적합성이 높 은 환경을 만들어 주게 된다. 다공성 $\mathrm{Ni}-\mathrm{Ti}$ 합금은 평균적으로 $30 \%-80 \%$ 다공성과 100-600 $\mu \mathrm{m}$ 의 공간 크기를 갖게 된다[3]. 이는 해면골과 유사한 형태로 높은 표면적을 제공해준다. 주변 의 조직액의 투과와 골조직의 침투는 일반적인 경우보다 2 배 이 상의 높은 속도로 일어나고 빠른 골유착을 만들어준다[11,12]. 동물실험에서 이러한 다공성 구조에서 좋은 bone implant contact (BIC)와 많은 양의 골침투가 일어나는 것을 확인했다 [13,14]. 47\%-66\%의 다공성과 260-510 $\mu \mathrm{m}$ 의 공간 크기에서 
높은 BIC를 보여준다는 연구도 있다[13]. 일반적으로 75\%-85\% 의 다공성과 $100 \mu \mathrm{m}$ 보다 공간 크기에서 빠른 골조직의 침투가 일어난다고 여겨진다[15].

또한 다공성 구조는 빈 공간을 통해 낮은 밀도와 낮은 강성 (stiffness)를 갖게 만들고, 탄성계수도 감소시킨다. 오스테나이 트 다공성 Ni-Ti합금의 탄성계수는 55-80 GPa로 티타늄 100 $\mathrm{GPa}$, 스테인리스 스틸 $190 \mathrm{GPa}$, 코발트 기반의 합금 $210 \mathrm{GPa}$ 의 수치에 비해 자연골의 탄성계수(해면골: $3 \mathrm{GPa}$ 이하, 피질 골: 12-17 GPa)에 가깝다[16]. 다른 금속에 비해 작은 탄성계수 는 인접 골조직과의 응력 차이가 감소시켜 stress shielding effect를 줄여준다[17]. Stress shielding effect는 골조직과 임플란 트 사이의 탄성계수의 큰 차이로 인해 발생하는 응력 효과로 주 변 경조직의 흡수와 임플란트의 실패를 야기할 수 있다[18,19]. 다공성 Ni-Ti합금을 이용해서 임플란트 주변에 적용할 수 있다 면 골침투에 유리한 환경을 만들면서 인접 조직과의 탄성 계수 를 감소시켜 골재생의 생리적인 측면과 기계적인 부분에서 기 존보다 개선된 특성이 나타날 수 있을 것이라 생각된다.

하지만 Ni-Ti합금 내의 니켈 이온은 이온 상태로 신체 내 노 출될 경우 천식, 알러지, 세포 과민반응, 세포독성, 유전자 독성 과 같은 심각한 부작용이 발생할 수 있다[20]. 다공성 구조에 의 해 인접 조직에 접하는 면적이 넓고, 주위 조직액에 노출되어 있 는 환경은 화학적 작용에 의한 부식을 발생시켜 니켈이온을 유 출 시킬 수 있다. 실험 연구에서 공간 크기가 커짐에 따라 부식 저항성이 2-3배 감소한 결과를 보여주었다[21]. 또한 임플란트 는 지속적인 부하를 받게 되는데, 부하에 의한 니켈 유출을 살펴 본 Xu 등[22]에 의하면 니켈유출량과 부하의 연관성은 없다고 했다. 의료용으로 사용되는 재료에 있어 가장 중요한 요소는 생 체 안전성이기 때문에 니켈의 유출에 대한 안정성 확보 및 이에 대한 좀 더 객관적이고 다양한 평가는 필수적이다.

니켈이온 유출 문제 해결은 표면처리를 통해 이루어지고 있 다. Ni-Ti합금은 초기 제조 공정상에서 매우 얇은 산화막(oxide layer)이 형성되어 부식과 산화를 예방해준다. 하지만 이 층은 결손을 가지거나 사용 중에 금이 가서 막의 보호 능력을 상실할 수 있다. 니켈의 유출은 이러한 결손부위를 통해 일어나게 된다. 그래서 $\mathrm{Ni}-\mathrm{Ti}$ 합금 표면에 안정성 있는 막의 두께를 형성하기 위 해 추가적인 표면처리가 진행되어야 한다[23]. 그래서 thermal annealing, oxygen plasma immersion ion implantation, presoaking in simulated body fluid solution, $\mathrm{TiN}, \mathrm{TiO}_{2}-\mathrm{PVD}$ coating, HA coating과 같은 다양한 방법이 적용되고 있다[2426]. 이러한 표면처리를 통해 니켈보다 좀 더 산화성이 큰 티타 늄의 산화를 통해 균일하고 동질의 두꺼운 $\mathrm{TiN}, \mathrm{TiO}_{2}$ 층을 형 성해 줘 니켈이온이 유출되는 것을 최소화되도록 한다. 산화막 의 두께가 니켈이온 유출을 방지하는 데 가장 중요한 부분이다
[27]. 이렇게 표면처리를 시행할 경우, 농출되는 니켈이온의 농 도는 매일 평균적으로 섭취하는 니켈 농도(150-900 $\mu \mathrm{g}$ per day)의 1/3-1/24 이하 수준으로 내려간다. 그리고 부식에 높 은 저항성을 갖게 된다[28,29]. $\mathrm{Gu}$ 등[30]은 니켈과 섬유모세포 의 영향 정도를 평가했는데, 표면처리되지 않은 다공성 $\mathrm{Ni}-\mathrm{Ti}$ 합 금 표면에는 어떠한 세포 부착도 일어나지 않은 반면 표면처리 를 시행한 경우 세포의 부착과 증식이 일어나는 것을 보고했다. Shabalovskaya 등[31,32]은 표면처리된 다공성 Ni-Ti합금은 in vitro상에서 생체적합한 특성을 갖는다고 발표했다. 표면처리가 잘 될 경우, 다공성 $\mathrm{Ni}-\mathrm{Ti}$ 합금은 인체 내에서 불활성의 상태로 우수한 생물학적 안정성을 가진다고 볼 수 있다.

다공성의 $\mathrm{Ni}-\mathrm{Ti}$ 합금은 이번 연구에서 골재생이 이루어졌고, 양호한 조직 반응을 나타냈다. 이러한 생체 반응을 통해 $\mathrm{Ni}-\mathrm{Ti}$ 합금 제조 시 표면처리가 이뤄졌다고 생각된다. 하지만 골재생 여부만 확인할 수 있는 것으로 다공성 Ni-Ti합금에서의 원활한 골재생의 양상을 파악하지는 못했다. 그리고 신생골의 형성은 확인했지만, 티타늄에서의 골재생 양상과 비교해보면 상당히 적은 양이 생성된 것을 확인 할 수 있다. 티타늄에서는 신생골의 비율은 4, 8주 모두에서 70\% 이상의 비율을 보였다[33-35]. 하 지만 이번 실험에서는 상대적으로 적은 $40 \%$ 이하의 신생골 비 율을 나타냈다. 이는 조직에서 보인 염증 반응의 차이에서 나타 난다고 생각된다. 염증의 원인은 실험과정상의 문제도 있겠지 만, 주로 조직편의 차이에서 기인한다고 생각된다. 염증 반응과 신생골 비율을 볼 때 다공성 $\mathrm{Ni}-\mathrm{Ti}$ 합금의 주위 조직에 대한 일 정량의 부정적인 영향이 있는 것으로 보인다. $\mathrm{Ni}-\mathrm{Ti}$ 합금의 표면 처리 정도를 정확히 확인할 수 없었지만 염증 상태로 볼 때 티 타늄에서 형성된 산화막과 비교해서 산화막의 정도가 부족하지 않았을까 추측해 본다. 향후 제조된 다공성 $\mathrm{Ni}-\mathrm{Ti}$ 합금의 표면에 대한 평가가 필요할 것이라 생각된다.

이번 연구는 다공성 $\mathrm{Ni}-\mathrm{Ti}$ 합금의 조직 반응과 골형성을 살펴 보는 것으로 기대했던 부분에 대해 확인할 수 있었다. 골형성 여부와 염증을 통한 조직 반응을 통해 실험에 적용되었던 다공 성 $\mathrm{Ni}-\mathrm{Ti}$ 합금의 생물학적 반응을 평가할 수 있었다. 하지만 개 체 수가 많지 않아 군 간의 통계적인 차이를 찾기에는 어려움 이 있었다. 부족한 신생골 형성과 양성의 염증 반응을 통해 향후 $\mathrm{Ni}-\mathrm{Ti}$ 시편 표면에 대한 면밀한 평가가 이루어져야 할 것으로 보 인다.

다공성 $\mathrm{Ni}$-Ti합금은 적절한 표면처리만 이루어진다면 생체 안정성이 적합하고 다공성의 구조를 쉽게 형성시킬 수 있어 골 형성 및 골유착에 유리한 환경을 만들어 줄 수 있다. 그리고 골 조직에 가까운 기계적인 특성을 통해 임플란트의 장기적 안정 성(longevity)에도 기여할 수 있을 것이라 생각된다. 하지만 이 번 연구 결과를 보면 재료 표면에 대한 추가적인 연구를 통해 안 
정성을 검증하는 것이 필요하다고 생각된다. 더 나아가 다공성 $\mathrm{Ni}-\mathrm{Ti}$ 를 임플란트 주위에 코팅한 상태로 실험을 하여 주위 골조 직 사이의 계면에서의 기계적인 안정성 여부도 평가가 이루어 져야 할 것으로 보인다. 다공성 $\mathrm{Ni}-\mathrm{Ti}$ 의 안정성과 효과적인 골 재생 양상이 확인된다면 충분히 효과적인 코팅 재료로 역할을 수행할 가능성이 있다.

\section{ACKNOWLEDGEMENTS}

This study was supported by research fund from Chosun University Dental Hospital, 2017.

\section{CONFLICTS OF INTEREST}

The authors declare that they have no competing interests.

\section{ORCID}

\author{
Gwi-Hyeon Min \\ https://orcid.org/0000-0002-4583-993X \\ Kyoung-Hoon Lee \\ https://orcid.org/0000-0003-1445-2692 \\ Se-Jin Sung \\ https://orcid.org/0000-0001-8785-2836 \\ Won-Pyo Lee \\ https://orcid.org/0000-0003-1911-3454 \\ Sang-Joun Yu \\ https://orcid.org/0000-0001-8818-549X \\ Byung-Ock Kim \\ https://orcid.org/0000-0001-8952-617X
}

\section{REFERENCES}

1. Buehler WJ, Gilfrich JV, Wiley RC. Effect of low-temperature phase changes on the mechanical properties of alloys near composition TiNi. J Appl Phys 1963;34:1475. doi: 10.1063/1.1729603.

2. Wang FE, Buehler WJ, Pickart SJ. Crystal structure and a unique "Martensitic" transition of TiNi. J Appl Phys 1965;36:3232-3239. doi: 10.1063/1.1702955.

3. Bansiddhi A, Sargeant TD, Stupp SI, Dunand DC. Porous NiTi for bone implants: a review. Acta Biomater 2008;4:773-782. doi: 10.1016/j.actbio.2008.02.009.
4. Afonina VS, Borisenko NI, Gizatullin RM, Gunderov DV, Kalashnikov VS, Koledov VV, Krasnoperov EP, Shavrov VG, Suslov VI, Yusov NA. Application of nanostructural nickel titanium implants with shape memory effect to modern dental practice. ESOMAT 2009;07001. doi: 10.1051/esomat/200907001.

5. Duyck J, Slaets E, Sasaguri K, Vandamme K, Naert I. Effect of intermittent loading and surface roughness on periimplant bone formation in a bone chamber model. J Clin Periodontol 2007;34:998-1006. doi: 10.1111/j.1600051X.2007.01135.X.

6. Li Y, Yang C, Zhao H, Qu S, Li X, Li Y. New developments of Ti-based alloys for biomedical applications. Materials (Basel) 2014;7:1709-1800. doi: 10.3390/ma7031709.

7. Abkowitz S, Siergiej JM, Regan RR. Titanium-nickel alloy manufacturing methods. United States Patent Office Patent 1969;3,700,434.

8. Xu JL, Bao LZ, Liu AH, Jin XF, Luo JM, Zhong ZC, Zheng YF. Effect of pore sizes on the microstructure and properties of the biomedical porous NiTi alloys prepared by microwave sintering. J Alloys Compd 2015;645:137-142. doi: 10.1016/ j.jallcom.2015.05.006.

9. Xiong JY, Li YC, Wang XJ, Hodgson PD, Wen CE. Titanium-nickel shape memory alloy foams for bone tissue engineering. J Mech Behav Biomed Mater 2008;1:269-273. doi: 10.1016/j.jmbbm.2007.09.003.

10. Li BY, Rong LJ, Li YY. Stress-strain behavior of porous $\mathrm{Ni}^{-}$ Ti shape memory intermetallics synthesized from powder sintering. Intermet 2000;8:643-646. doi: 10.1016/S09669795(99)00140-5.

11. Assad M, Chernyshov A, Leroux MA, Rivard CH. A new porous titanium-nickel alloy: part 1. Cytotoxicity and genotoxicity evaluation. Biomed Mater Eng 2002;12:225-237.

12. Likibi F, Assad M, Coillard C, Chabot G, Rivard CH. [Bone integration and apposition of porous and non porous metallic orthopaedic biomaterials]. Ann Chir 2005;130:235241. French. doi: 10.1016/j.anchir.2004.12.006.

13. Kujala S, Ryhänen J, Danilov A, Tuukkanen J. Effect of porosity on the osteointegration and bone ingrowth of a weight-bearing nickel-titanium bone graft substitute. Biomaterials 2003;24:4691-4697. doi: 10.1016/s01429612(03)00359-4.

14. Ayers RA, Simske SJ, Bateman TA, Petkus A, Sachdeva RL, Gyunter VE. Effect of nitinol implant porosity on cranial bone ingrowth and apposition after 6 weeks. J Biomed Mater Res 1999;45:42-47. doi: 10.1002/(sici)10974636(199904)45:1〈42::aid-jbm6〉3.0.co;2-q.

15. Mour M, Das D, Winkler T, Hoenig E, Mielke G, Morlock MM, Schilling, AF. Advances in porous biomaterials for dental and orthopaedic applications. Mater 2010;3:29472974. doi: 10.3390/ma3052947.

16. Geetha M, Singh AK, Asokamani R, Gogia AK. Ti based biomaterials, the ultimate choice for orthopaedic implants 
- a review. Prog Mater Sci 2009;54:397-425. doi: 10.1016/ j.pmatsci.2008.06.004.

17. Nagels J, Stokdijk M, Rozing PM. Stress shielding and bone resorption in shoulder arthroplasty. J Shoulder Elbow Surg 2003;12:35-39. doi: 10.1067/mse.2003.22.

18. Niinomi M. Metallic biomaterials. J Artif Organs 2008;11:105-110. doi: 10.1007/s10047-008-0422-7.

19. Niinomi M, Nakai M, Hieda J. Development of new metallic alloys for biomedical applications. Acta Biomater 2012;8:3888-3903. doi: 10.1016/j.actbio.2012.06.037.

20. Cempel M, Nikel G. Nickel: a review of its sources and environmental toxicology. Pol J Environ Stud 2006;15:375382.

21. Denkhaus E, Salnikow K. Nickel essentiality, toxicity, and carcinogenicity. Crit Rev Oncol Hematol 2002;42:35-56. doi: 10.1016/s1040-8428(01)00214-1.

22. Xu JL, Jin XF, Luo JM, Zhong ZC. Fabrication and properties of porous NiTi alloys by microwave sintering for biomedical applications. Mater Lett 2014;124:110-112. doi: 10.1016/j.matlet.2014.03.088.

23. Pellegrini G, Francetti L, Barbaro B, Del Fabbro M. Novel surfaces and osseointegration in implant dentistry. J Investig Clin Dent 2018;9:e12349. doi: 10.1111/jicd.12349.

24. Toker SM, Canadinc D, Maier HJ, Birer O. Evaluation of passive oxide layer formation-biocompatibility relationship in NiTi shape memory alloys: geometry and body location dependency. Mater Sci Eng C Mater Biol Appl 2014:36:118-129. doi: 10.1016/j.msec.2013.11.040.

25. Wu SL, Liu X, Chan YL, Ho JPY, Chung CY, Chu PK, Chu CL, Yeung KWK, Lu WW, Cheung KMC, Luk KDK. Nickel release behavior, cytocompatibility, and superelasticity of oxidized porous single-phase NiTi. J Biomed Mater Res A 2007;81A:948-955. doi: 10.1002/jbm.a.31115.

26. Ho JPY, Wu SL, Poon RWY, Chung CY, Tjong SC, Chu PK, Yeung KWK, Lu WW, Cheung KMC, Luk KDK. Oxygen plasma treatment to restrain nickel out-diffusion from porous nickel titanium orthopedic materials. Surf Coat Technol 2007;201:4893-4896. doi: 10.1016/ j.surfcoat.2006.07.072.
27. Lemaire V, Sicotte B, Allard S. Surface modification treatments to reduce ni leaching from porous nitinol. In: Lefebvre LP, Banhart J, Dunand D, editors. Porous metals and metallic foams: proceedings of the fifth international conference on porous metals and metallic foams. Lancaster: DEStech Publications, Inc.; 2008.

28. Elahinia MH, Hashemi M, Tabesh M, Bhaduri SB. Manufacturing and processing of NiTi implants: a review. Prog Mater Sci 2012;57-911-946. doi:10.1016/ j.pmatsci.2011.11.001

29. Schrooten J, Assad M, Van Humbeeck J, Leroux MA. In vitro corrosion resistance of porous NiTi intervertebral fusion devices. Smart Mater Struct 2007;16:S145-S154.

30. Gu YW, Li H, Tay BY, Lim CS, Yong MS, Khor KA. In vitro bioactivity and osteoblast response of porous NiTi synthesized by SHS using nanocrystalline Ni-Ti reaction agent. J Biomed Mater Res A 2006;78:316-323. doi: 10.1002/jbm. a.30743.

31. Shabalovskaya SA. Surface, corrosion and biocompatibility aspects of Nitinol as an implant material. Biomed Mater Eng 2002;12:69-109.

32. Shabalovskaya S, Ryhanen J, Yahia LH. Bioperformance of nitinol: surface tendencies. Shape Memory Mater Its Appl 2001;394:131-138. doi: 10.4028/www.scientific.net/ MSF.394-395.1310.

33. Guerra I, Morais Branco F, Vasconcelos M, Afonso A, Figueiral H, Zita R. Evaluation of implant osseointegration with different regeneration techniques in the treatment of bone defects around implants: an experimental study in a rabbit model. Clin Oral Implants Res 2011;22:314-322. doi: 10.1111/j.1600-0501.2010.02002.x.

34. Dahlin C, Sennerby L, Lekholm U, Linde A, Nyman S. Generation of new bone around titanium implants using a membrane technique: an experimental study in rabbits. Int J Oral Maxillofac Implants 1989;4:19-25.

35. Berglundh T, Lindhe J. Healing around implants placed in bone defects treated with Bio-Oss. An experimental study in the dog. Clin Oral Implants Res 1997;8:117-124. doi: 10.1034/j.1600-0501.1997.080206.x. 